Original Research Article

\title{
Cost variation analysis of oral anti-diabetic agents available in drug store of the tertiary care hospital and in Indian market
}

\author{
Aparna Chincholkar*, Ganesh Pentewar
}

Department of Pharmacology, Mimer Medical College, Talegaon, Dabhade, Pune 410507, India

Received: 12 May 2017

Revised: 01 June 2017

Accepted: 06 June 2017

*Correspondence to: Dr. Aparna Chincholkar, Email: aparnaatr@gmail.com

Copyright: (C) the author(s), publisher and licensee Medip Academy. This is an openaccess article distributed under the terms of the Creative Commons Attribution NonCommercial License, which permits unrestricted noncommercial use, distribution, and reproduction in any medium, provided the original work is properly cited.

\begin{abstract}
Background: Diabetes, a chronic disorder and requires life-long treatment. Cost of drug treatment is a major hurdle related to medication compliance in Type 2 Diabetes Mellitus. The objective of the study was to find out the cost of antidiabetic drugs available in the drug store of a tertiary care hospital and compare it with the different brands of the same drugs available in Indian market. To evaluate the difference in cost of different brands of same active drug by calculating percentage variation of cost.

Methods: Cost of single compound and combination compound oral antidiabetic drugs available in drug store and those same drugs in Indian market manufactured by different companies, in the same strength, number and dosage form. The percentage price variation between minimum and maximum cost of drugs were calculated. The percentage difference in cost of antidiabetic drugs available in drug store and in the Indian market was calculated.

Results: The percentage price variation of oral antidiabetic drugs available in drug store was found to be as follows. In sulfonylureas, it was highest in Glimepiride (2mg) 1962, 96\%, among biguindes, Metformin (500mg) 3012.5\%, among alpha glucosidase inhibitors Voglibose $(0.2 \mathrm{mg}) 387.17 \%$. Voglibose $(0.3 \mathrm{mg}) 361.30 \%$. Among combination therapy Voglibose $(0.3 \mathrm{mg})+$ Metformin (500mg) 2809\% showed maximum price variation.

Conclusions: The average percentage price variation of different brands of the same drug is very wide and hence the physician must keep this in mind while prescribing since the drug treatment of type II diabetes mellitus is usually lifelong. Hence, manufacturing companies should aim to decrease the price variation while maintaining the therapeutic efficacy. Drug store of tertiary care hospital should try to provide the oral antidiabetic drug with least cost and sell the generic drugs.
\end{abstract}

Keywords: Brands, Diabetes mellitus, Drug store, Manufacturing companies, Oral antidiabetic drugs, Price variation

\section{INTRODUCTION}

Diabetes is the most common non communicable chronic disease worldwide. Diabetes mellitus is on alarming rise in India The International Diabetes Federation (IDF) estimates the total number of diabetic subjects to be around 40.9 million in India and this is further set to rise to 69.9 million by the year 2025.Management of Type I diabetes mellitus depends mainly on insulin, whereas oral antidiabetics are first line treatment for type II diabetes mellitus. It requires lifelong treatment.
Pharmaco-economics plays a major role in practice of medicine in once life. In the developing countries the cost of drugs is a major concern to both physician and patient.

The Indian pharmaceutical market is hub for choice of drugs to select with maximum price to minimum price under different brands and generic Drugs. ${ }^{1}$ In India, in $1979,80-85 \%$ of the drugs in the market were under price control which has slowly decreased and by 2002 only 15 $20 \%$ drugs were under price control. ${ }^{2}$ 
On an average a person spends $20 \%$ of his or her income for the treatment of diabetes per year. ${ }^{3}$ Cost of an drug constitutes an essential part of rational drug therapy. ${ }^{4}$ In spite of government of India's attempt to prevent unjustifiable pricing of drugs by enacting the Drug Price Control Order (DPCO), 1970 as well as incorporating the National List of Essential Medicine (NLEM), there exist a wide variation of drug prices within one drug with availability of various brands. ${ }^{5}$ National Pharmaceutical Pricing Authority (NPPA), deciding to bring them under price control. NPPA has fixed the prices of 108 formulation packs of 50 anti-diabetic and cardiovascular medicines.

There are more than 100,000 formulations available for all the category of drugs under the umbrella of various brand names, there is no system of registration of these formulations. ${ }^{5}$

It is necessary for a clinician to prescribe most effective, appropriate and economical treatment regimen available, leading to increased adherence to therapy in the longterm treatment of diabetes. High cost of medicines is one of the important reasons for the noncompliance by the patient, thus leading to poor control of blood sugar level and increasing the morbidity associated with the diabetes.

Very few studies are done to find out difference in cost of antidiabetic drugs available in a drug store of tertiary care hospital attached to a medical college and those with same active ingredient with different brand names available in Indian market.

So, the present study was planned which will help in noting the variation in prices and the drug store authority to choose a brand of oral antidiabetic drug to be kept in drug store for dispensing.

\section{Aim and objectives}

- To find the cost of oral anti-diabetics of different brand names of one compound and combination of compounds sold in medical store of the tertiary care hospital and in Indian market.

- To analyze the difference in cost of different brands for the same dosage same active drug by calculating percentage variation of cost.

- To compare the cost and percentage price variation of single and combination therapy of oral anti diabetic agents across the different brands available in drug store and the Indian market.

\section{METHODS}

Design of the study was an analytical study.

The study was conducted by the Department of Pharmacology, MIMER Medical College and BSRTCH Talegaon.

- A list of oral antidiabetic drugs available in the drug store was found out

- Price of these different oral antidiabetic drugs per tablet in Indian rupees was obtained from http://www.medguideindia.com

- Cost of same drug in same strength, dosage form manufactured by different companies was found out from http://www.medguideindia.com. ${ }^{6}$

- The difference in the maximum and minimum price of the same drug formulation manufactured by different pharmaceutical companies was calculated.

- The percentage variation in price was calculated. Percentage price variation was calculated as price of most expensive brand-Price of least expensive brand X 100 divided by Price of least expensive brand.

- The drugs being manufactured by only one company or being manufactured by different companies however, in different strengths were excluded.

- The cost of all the brands of the antidiabetic drugs available in the drug store was tabulated. All the prices of each drug were added together and the mean value for each drug was calculated by dividing total cost by number of brands.

- The percentage difference in cost of drugs available in drug store and the Indian market was found out.

\section{Statistical analysis}

Findings of our study were expressed as absolute numbers as well as percentage.

\section{RESULTS}

The prices on a total of 9 drugs (6 single and 3 combination preparations), available in drug store belonging to 3 different classes in 14 different formulations were analyzed. These 14 formulations are manufactured by different pharmaceutical companies.

Table 1: Price variation in sulfonylurea group of drugs.

\begin{tabular}{|llllllllll|}
\hline Drug & $\begin{array}{l}\text { Formula- } \\
\text { tion }\end{array}$ & Dose & $\begin{array}{l}\text { Manufacturing } \\
\text { company }\end{array}$ & $\begin{array}{l}\text { Mini. } \\
\text { price }\end{array}$ & $\begin{array}{l}\text { Maxi. } \\
\text { price }\end{array}$ & $\begin{array}{l}\% \\
\text { variation }\end{array}$ & $\begin{array}{l}\text { Price of brand } \\
\text { available in } \\
\text { drug store }\end{array}$ & $\begin{array}{l}\text { Mean } \\
\text { price }\end{array}$ & $\begin{array}{l}\% \\
\text { difference } \\
\text { in cost }\end{array}$ \\
\hline Glipizide & 1 & $2.5 \mathrm{mg}$ & 15 & 0.26 & 0.65 & 150 & 0.50 & 0.47 & 106 \\
\hline \multirow{2}{*}{ Glimepiride } & 2 & $1 \mathrm{mg}$ & 144 & 0.72 & 6.25 & 768.05 & 5.31 & 2.83 & 187 \\
\hline
\end{tabular}


Table 2: Price variation in biguanide group of drugs.

\begin{tabular}{|llll|llllll|}
\hline Drug & $\begin{array}{l}\text { Formula- } \\
\text { tion }\end{array}$ & Dose & $\begin{array}{l}\text { Manufacturing } \\
\text { company }\end{array}$ & $\begin{array}{l}\text { Mini. } \\
\text { price }\end{array}$ & $\begin{array}{l}\text { Maxi. } \\
\text { price }\end{array}$ & $\begin{array}{l}\% \\
\text { variation }\end{array}$ & $\begin{array}{l}\text { Price of brand } \\
\text { available in } \\
\text { drug store }\end{array}$ & $\begin{array}{l}\text { Mean } \\
\text { price }\end{array}$ & $\begin{array}{l}\% \\
\text { difference } \\
\text { in cost }\end{array}$ \\
\hline Metformin & 2 & $250 \mathrm{mg}$ & 12 & 0.40 & 0.90 & 125 & 1.03 & 0.57 & 180 \\
\hline $\begin{array}{l}\text { Metformin } \\
\text { SR }\end{array}$ & 2 & $500 \mathrm{mg}$ & 97 & 0.08 & 2.49 & 3012.5 & 1.33 & 1.11 & 119 \\
\hline
\end{tabular}

Metformin-500mg show a significant price variation

Table 3: Price variation among alpha glucosidase inhibitor group of drug.

\begin{tabular}{|llllllllll|}
\hline Drug & $\begin{array}{l}\text { Formula- } \\
\text { tion }\end{array}$ & Dose & $\begin{array}{l}\text { Manufacturing } \\
\text { company }\end{array}$ & $\begin{array}{l}\text { Mini. } \\
\text { price }\end{array}$ & $\begin{array}{l}\text { Maxi. } \\
\text { price }\end{array}$ & $\begin{array}{l}\text { \% } \\
\text { variation }\end{array}$ & $\begin{array}{l}\text { Price of brand } \\
\text { available in } \\
\text { drug store }\end{array}$ & $\begin{array}{l}\text { Mean } \\
\text { price }\end{array}$ & $\begin{array}{l}\% \\
\text { difference } \\
\text { in cost }\end{array}$ \\
\hline Voglibose & 2 & $0.2 \mathrm{mg}$ & 36 & 1.95 & 9.5 & 387.17 & $7.3,8$ & 6.15 & 118,130 \\
\cline { 2 - 10 }
\end{tabular}

The two strengths of voglibose have nearly same price variation

Table 4: Price variation amongst combination therapy.

\begin{tabular}{|llllllllll|}
\hline Drug & $\begin{array}{l}\text { Formula- } \\
\text { tion }\end{array}$ & Dose & $\begin{array}{l}\text { Manufacturing } \\
\text { company }\end{array}$ & $\begin{array}{l}\text { Mini. } \\
\text { price }\end{array}$ & $\begin{array}{l}\text { Maxi. } \\
\text { price }\end{array}$ & $\begin{array}{l}\% \\
\text { variation }\end{array}$ & $\begin{array}{l}\text { Price of brand } \\
\text { available in } \\
\text { drug store }\end{array}$ & $\begin{array}{l}\text { Mean } \\
\text { price }\end{array}$ & $\begin{array}{l}\% \\
\text { difierence } \\
\text { in cost }\end{array}$ \\
\hline $\begin{array}{l}\text { Glipizide+ } \\
\text { Metformin }\end{array}$ & 1 & $5+500$ & 41 & 0.67 & 3.48 & 1.05 & 1.34 & 419.40 & 78 \\
\hline $\begin{array}{l}\text { Glimipride+ } \\
\text { Metformin }\end{array}$ & 4 & $1+500$ & 112 & 1.2 & 7.9 & $5.31,5$ & 4.01 & 558,33 & 132,124 \\
\hline $\begin{array}{l}\text { Voglibose+ } \\
\text { Metformin }\end{array}$ & 1 & $2+500$ & 154 & 2.50 & 14.3 & $7.11,10.81$ & 5.52 & 472 & 128,195 \\
\hline
\end{tabular}

Table 5: Relationship between percent price variation and no. of manufacturing companies.

\begin{tabular}{|lll|}
\hline & $\begin{array}{l}\text { No. of } \\
\text { Manufacturing } \\
\text { companies }\end{array}$ & $\begin{array}{l}\text { percent } \\
\text { price } \\
\text { variation }\end{array}$ \\
\hline Glipizide & 15 & 150 \\
\hline Glimepiride 1mg & 144 & 768.05 \\
\hline Glimepiride 2mg & 147 & 1962,96 \\
\hline Metformin 250 mg & 12 & 125 \\
\hline Metformin 500 mg & 97 & 3012.5 \\
\hline Metformin SR 500mg & 39 & 340 \\
\hline Metformin SR 1000mg & 39 & 1150 \\
\hline Voglibose 0.2 mg & 36 & 387.17 \\
\hline Voglibose 0.3 mg & 38 & 361.30 \\
\hline Glipizide+Metformin & 41 & 419.40 \\
\hline $\begin{array}{l}\text { Glimipride (1mg) } \\
\text { +Metformin(500mg) }\end{array}$ & 112 & 558,33 \\
\hline $\begin{array}{l}\text { Glimipride (2mg) } \\
\text { +Metformin(500mg) }\end{array}$ & 154 & 472 \\
\hline $\begin{array}{l}\text { Glimipride (1mg) } \\
\text { +Metformin(1000mg) }\end{array}$ & 7 & 168.65 \\
\hline $\begin{array}{l}\text { Glimipride (2mg) } \\
\text { +Metformin(1000mg) }\end{array}$ & 11 & 222.22 \\
\hline Voglibose+Metformin & 11 & 2809 \\
\hline
\end{tabular}

In this group, glimepiride $(1 \mathrm{mg})$ shows maximum price variation of $655.38 \%$, while glipizide (10mg) shows variation of $38.88 \%$. There is a significant difference between mean price and price of brand available in drug store of glimepiride $1 \mathrm{mg}$ and $2 \mathrm{mg}$. The mean price of Glipizide tablet is 0.47 which is comparable to price of brand available in the medical store.

In Combination therapy, total 3 combination therapies were analyzed. In this, voglibose $(0.3)+$ metformin (500mg) combination shows the maximum variation up to $2809 \%$.

\section{DISCUSSION}

There exists a wide range of variation in the cost of drugs marketed in India. ${ }^{7}$ Indian market is a predominantly branded generic market i.e. more than one company sells a particular drug under different brand names apart from innovator company.

Drugs used in the management of diabetes mellitus were selected for cost analysis as it is one of the major causes 
of morbidity and mortality and the treatment requires lifelong continuous prescription drug use.

As per results there exists a huge price variation around $100 \%$ among oral antidiabetic drugs which is not acceptable situation for patients. This is in accordance with the study done in Nepal and pharmacoeconomic study of antidiabetic drugs done in Navi Mumbai. ${ }^{8,9}$

It is observed from our results that there is a wide (up to3012\%) variation in prices of drugs manufactured by different pharmaceutical companies by varied brand names of same generic drug. The reasons for this price variation could be as follows: ${ }^{10-13}$

1. The existing market structure of the pharmaceutical industry

2. Asymmetry of information or imperfect information

3. Industry costs

4. Government regulations and pricing policies

5. To provide better quality of medication, doctors prescribe medication from reputed companies even though the cost is high.

As the percentage price variation is quite wide leading to cost burden on the consumer. In India most of the patients are paying out of their pockets for their medical bills and are not covered by insurance schemes unlike developed countries. It will be better if physician have a list of different brands of a drug available in market with the cost as to prescribe a brand with less cost. Wherever possible a cheaper brand should be prescribed because the superiority of any particular brand over the others has never been proved scientifically. That will lead to less economic burden on a patient.

There is a need for concerted action from regulatory authorities, doctors, pharmacists and general public at large to address this issue of antidiabetic drugs price variation.

Government should bring all life saving and essential drugs under price control of NPPA. The government has also put in place mechanisms such as the Drug Price Control Order (DPCO) and the National Pharmaceutical Pricing Authority (NPPA) to address the issue of affordability and availability of medicines. Currently, very few medicines are under drug prices control. Government has to notice to all prescribers not write brand name, only generic name.

From our study it is also clear that, price variation was not directly related to the number of companies manufacturing a particular drug which is different from other study. 5,7

Pharmacists do not dispense the same brand as prescribed by the doctor and try to substitute it, with other alternatives, quoting the reason of non availability. This is often done with vested interest for economic gains as some brands have a higher profit margin. ${ }^{7}$

Results also highlight the percentage difference in cost of brand of a drug available in a drug store and the Indian market. The drug stores of tertiary care hospital attached to medical college can provide the brand of a drug with less price.

\section{CONCLUSION}

The study highlights that there is a huge price variation in cost of oral antidiabetic drugs. Government should have a policy whereby the prices of branded-generic drugs can be made realistic and affordable to common man. We need to have legislation to that effect.

The situation can be improved by incorporating an analysis of prescription costs in the medical curriculum and by providing updated and complete information regarding bioequivalence, quality and cost of the pharmaceutical preparation to the doctors.

At the hospital level authorities and concerned committees have to frame policies on these aspects so that patient can afford the drug treatment.

Funding: No funding sources

Conflict of interest: None declared

Ethical approval: The study was approved by the Institutional Ethics Committee

\section{REFERENCES}

1. Rao NVR, Chowdary BM, Mergaret TM. Cost analysis study of oral anti-diabetic drugs Available in Indian Govt generic (JAN AUSHADHI, JEEVANDHARA) drugs and brand drugs market in rural/ urban area of Guntur, Andhrapradesh, India. World J of Phar Res. 2015;4(5):2201-10.

2. Jana S, Mondal P. Pharmacoeconomics: The need to sensitize undergraduate medical students. Indian Pharmacol. 2005;37:277-8.

3. Jha NJ. Cost Analysis for Management of Type-2 Diabetes: A Case Study of Rural and Urban Setting. Journal of Nepal Health Research Council. October 2004;2(2):55-9.

4. Phatak AM, Hotwani JH, Deshmukh KR, Panchal SS, Naik MS. Cost analysis of long established and newer oral antiepileptic drugs available in the Indian market. Int J Med Res Health Sci. 2015;4(4):744-8.

5. Hussain S, Pharm M. Cost variation analysis of Oral Hypoglycaemic agents available in Indian market: An Economic Perspective. International Journal of Pharma Sciences and Research (IJPSR). 2015;6(5):913-8.

6. Prices of brand drugs, Medguideindia. Available at: http://www.medguideindia.com/show_brand.php 
7. Jadhav NB, Bhosale MS, Adhav CV. Cost analysis study of oral antidiabetic drugs available in Indian market. Int J Med Res Health Sci. 2013;2(1):63-9.

8. Binaya S. Cost analysis of oral hypoglycemic agents available in Nepalese market. MJSBH. 2014;13(2):69.

9. Tiwari A, Yadav P. pharmacoeconomic study of antidiabetic drugs. Proceedings of $27^{\text {th }}$ IRF International Conference, $24^{\text {th }}$ May 2015, Pune, India, ISBN: 978-93-85465-17-8 36.

10. Misra B, Jain SK, Mehta Y. A study on availability and prices of medicines in India. National Pharmaceutical Pricing Authority; 2002. Available at: http://nppaindia.nic.in/index1.html
11. Sarkar PK. A rational drug policy. Indian J Med Ethics. 2004;1(1):11-2.

12. Roy V, Rewari S. Ambiguous drug pricing: a physician's dilemma. Indian J Pharmacol. 1998;30(6):404-7.

13. Wertheimer AI, Grumer SK. Overview of international pharmacy pricing. Pharmacoeconomics. 1992 Dec 1;2(6):449-55.

Cite this article as: Chincholkar A, Pentewar G. Cost variation analysis of oral anti-diabetic agents available in drug store of the tertiary care hospital and in Indian market. Int J Basic Clin Pharmacol 2017;6:1794-8. 